PAPER

\title{
A multi-dimensional study of the emotion in current Japanese popular music
}

\author{
Ryo Yoneda* and Masashi Yamada \\ Graduate School of Engineering, Kanazawa Institute of Technology, \\ 7-1 Ohgigaoka, Nonoich, 921-8501 Japan
}

(Received 22 March 2012, Accepted for publication 5 September 2012)

\begin{abstract}
Musical psychologists illustrated musical emotion with various numbers of dimensions ranging from two to eight. Most of them concentrated on classical music. Only a few researchers studied emotion in popular music, but the number of pieces they used was very small. In the present study, perceptual experiments were conducted using large sets of popular pieces. In Experiment 1, ten listeners rated musical emotion for $50 \mathrm{~J}$-POP pieces using $17 \mathrm{SD}$ scales. The results of factor analysis showed that the emotional space was constructed by three factors, "evaluation," "potency" and "activity." In Experiment 2, three musicians and eight non-musicians rated musical emotion for 169 popular pieces. The set of pieces included not only J-POP tunes but also Enka and western popular tunes. The listeners also rated the suitability for several listening situations. The results of factor analysis showed that the emotional space for the 169 pieces was spanned by the three factors, "evaluation," "potency" and "activity," again. The results of multiple-regression analyses suggested that the listeners like to listen to a "beautiful" tune with their lovers and a "powerful" and "active" tune in a situation where people were around them.
\end{abstract}

Keywords: Musical emotion, Popular music, J-POP, Semantic differential method, Factor analysis

PACS number: 43.75.Cd [doi:10.1250/ast.34.166]

\section{INTRODUCTION}

Musical emotion is expressed by various adjectives such as cheerful, tender, majestic, etc. This implies that musical emotion is illustrated by a multi-dimensional space. Many musical psychologists illustrated this space with various numbers of dimensions. For example, Hevner illustrated the musical emotion using a simple two-dimensional space. She selected short pieces of music and manipulated their mode, melodic direction, harmony, and rhythm, systematically [1]. In another study, she also manipulated tempo and pitch level [2]. These variants as well as the original versions were presented, and the listeners were requested to show the emotional features of the stimuli on the two-dimensional space in her experiments.

Osgood and his colleagues invented SD (semantic differential) method to clarify dimensions of an emotional space for a set of concepts, and they showed that the emotional spaces for various sets of concepts were constructed by three factors: "evaluation," "potency" and

*e-mail: r_yoneda@venus.kanazawa-it.ac.jp "activity" [3]. Using the SD method, Russell showed that general affection was illustrated by a circumplex model, which was spanned by "valence" and "arousal" factors [4]. This model was almost identical to the two-dimensional space by which Hevner illustrated the musical emotion. Schubert pointed out that the "valence" and "arousal" dimensions agree, in principle, with two of the three dimensions Osgood and his colleagues proposed; "evaluation" and "activity" [5]. Taniguchi proposed more complex structure to illustrate the musical emotion. He used 90 excerpts of classical music works as stimuli, and showed that the emotional space for them was constructed by five or eight factors [6].

Most of the dimensional studies described above concentrated on classical music, and only a few studies illustrated the musical emotion in popular music using multi-dimensional spaces. Iwamiya conducted a perceptual experiment using popular music, in the contexts of car audio with music [7]. He illustrated the impression of music using three-dimensional spaces. Yamada, Fujisawa and Komori also investigated musical emotion in the context of a video racing game, and showed that the musical emotion in a set of popular music was illustrated 
by a three-dimensional space [8]. However, the number of musical pieces used in these studies was small, and the dimensions of musical emotion in popular music have not been clarified yet, using a large number of pieces.

Therefore, in the present study, perceptual experiments were conducted, using large sets of pieces of popular music which reflects the current popular music scene in Japan, to reveal the dimensions of musical emotion in Japanese popular music. The number of listeners and the number of musical pieces have a compensating relationship for a given time during the listening experiment. In the present study, the number of musical pieces was given priority over the number of listeners.

Moreover, the correlations between the emotional features and suitable situations of listening to popular music were also investigated, in the present study. The relationship between musical emotion and acoustic parameters has been studied by many researchers. They suggested that tempo was one of the most important parameters for musical emotion [9-11]. However, most of these studies used short musical materials which varied performing tempo, and the relation between musical emotion and tempo has not been clarified in a large number of various musical pieces. In the present study, the relationship between the tempo and the musical emotion is also investigated.

\section{EXPERIMENT 1}

\subsection{Musical Stimuli}

The musical pieces used in Experiment 1 were defined in the following way: First, the top 50 musicians were selected based on the download ranking from June to October 2009 in LISMO, which provides the most popular music retrieval services in Japan. Then the top-selling piece until December 2010 was selected for each of the 50 musicians based on the web site, Oricon Style (http:// www.oricon.co.jp/), the most famous music ranking site in Japan. The selected musical pieces are shown in Table 1 . The play time of the pieces was ranged from 3.5 to $7.0 \mathrm{~min}$.

\subsection{Procedure}

Ten listeners, nine of whom were male and one was female, listened to the 50 pieces and rated the emotional features of them. Their ages ranged from 20 to 31 years old. Two of the listeners were musicians, and listened to music at least several pieces from various musical genres a day. The other eight listeners were non-musicians, but listened to J-POP tunes through music players, car audio, TV programs, and internet at least once a day. In one trial, a listener was presented a piece through headphones. The listener was not allowed to rate while a piece of music was presented. After the piece was finished, the listener rated the emotional features of it using 17 semantic
Table 1 Musical pieces used in Experiment 1.

\begin{tabular}{|c|c|}
\hline Best-selling piece & Artist \\
\hline $\mathrm{A} \cdot \mathrm{RA} \cdot \mathrm{SHI}$ & ARASHI \\
\hline Kiseki & GReeeeN \\
\hline Good-bye days & YUI \\
\hline Tada...Aitakute & EXILE \\
\hline Sakurazaka & Masaharu Fukuyama \\
\hline Arigatou & Ikimonogakari \\
\hline Sekai ni Hitotsu Dake no Hana & SMAP \\
\hline Tomorrow never knows & Mr. Children \\
\hline Ningyo Hime & Kumi Koda \\
\hline BREAK OUT! & Tohoshinki \\
\hline Honnou & Sheena Ringo \\
\hline I LOVE YOU & Yutaka Ozaki \\
\hline Order Made & RADWIMPS \\
\hline Ai wo Komete Hanataba wo & Superfly \\
\hline monochrome & Ayumi Hamasaki \\
\hline Asita ga Kurunara & JUJU \\
\hline Uso & SID \\
\hline Dear Lonely Girl & Miliyah Kato \\
\hline Himawari & Yuusuke \\
\hline Jyunrenka & Shonannokaze \\
\hline GOLDFINGER '99 & Hiromi Go \\
\hline Aitakute Aitakute & Kana Nishino \\
\hline $\begin{array}{l}\text { Ai no Mama ni Wagamama ni Boku } \\
\text { wa Kimi Dake wo Kizutsukenai }\end{array}$ & $\mathrm{B}^{\prime} \mathrm{z}$ \\
\hline Hitomi wo Tozite & Ken Hirai \\
\hline Tentai Kansoku & BUMP OF CHICKEN \\
\hline Zenryoku Shounen & Sukimaswitch \\
\hline Mikazuki & Ayaka \\
\hline HONEY & $\mathrm{L}^{\prime} \mathrm{Arc} \sim \mathrm{en} \sim \mathrm{Ciel}$ \\
\hline Make my day & Yui Aragaki \\
\hline STARS & Mika Nakashima \\
\hline Winter, again & GLAY \\
\hline Tsubomi & Kobukuro \\
\hline Rirura Riruha & Kaela Kimura \\
\hline Tobenai Tori & Yuzu \\
\hline CAN YOU CELEBRATE? & Namie Amuro \\
\hline Lovin' Life & $\begin{array}{l}\text { FUNKY MONKEY } \\
\text { BABYS }\end{array}$ \\
\hline Addicted To You & Hikaru Utada \\
\hline ANOTHER WORLD & GACKT \\
\hline Gekkouka & Janne Da Arc \\
\hline Guuzenno Kakuritu & GIRL NEXT DOOR \\
\hline SOS & TAMURAPAN \\
\hline White Love & SPEED \\
\hline love the world & Perfume \\
\hline TSUNAMI & Southern All Stars \\
\hline Boyfriend & aiko \\
\hline Hakanaku mo Towa no Kanashi & UVERworld \\
\hline Real Face\#1 & KAT-TUN \\
\hline Here We Go feat. VERBAL & May J. \\
\hline Around The World & MONKEY MAJIK \\
\hline Sakuranbo & Ai Otsuka \\
\hline
\end{tabular}

differential (SD) scales shown in Table 2. The SD scales were shown in Japanese on the response sheets, in fact. These were bipolar seven-step scales, e.g., "very happy," "fairly happy," "slightly happy," ..., "very sad." The SD scales appeared on a response sheet in a random order for 
Table 2 Semantic differential (SD) scales and factor loadings of them in Experiment 1.

\begin{tabular}{|c|c|c|c|c|}
\hline \multicolumn{2}{|c|}{ SD scale } & \multicolumn{3}{|c|}{ Factor } \\
\hline English & Japanese & Evaluation & Potency & Activity \\
\hline Mixed-Neat & ごちゃごちゃしたーすっきりした & 0.856 & -0.383 & -0.132 \\
\hline Clean-Dirty & きれいなーきたない & -0.825 & 0.140 & 0.140 \\
\hline Showy-Humble & 派手なー地味な & 0.540 & -0.685 & -0.294 \\
\hline Agitated-Calm & 落ち着きのないー落ち着いた & 0.713 & -0.507 & -0.322 \\
\hline Fresh-Sordid & さわやかなーむさくるしい & -0.757 & 0.226 & -0.293 \\
\hline Heavy-Light & 重い一軽い & 0.338 & -0.349 & 0.759 \\
\hline Dark-Bright & 暗いー明るい & 0.118 & 0.025 & 0.984 \\
\hline Cheerful-Gloomy & 陽気なー悲しい & 0.133 & -0.063 & -0.977 \\
\hline Weak-Strong & 弱々しいーカ強い & -0.245 & 0.856 & 0.040 \\
\hline Hard-Soft & かたいーやわらかい & 0.784 & -0.539 & 0.011 \\
\hline Loose-Tight & たるんだーひきしまった & -0.168 & 0.866 & -0.209 \\
\hline Powerful-Powerless & 迫カのある-もの足りない & 0.318 & -0.890 & 0.022 \\
\hline Monotonous-Varied & 単調なー変化のある & 0.045 & 0.613 & -0.043 \\
\hline Tranquil-Restless & のどかなーせかせかした & -0.633 & 0.604 & 0.247 \\
\hline Pleasant-Unpleasant & 快いー不快な & -0.892 & -0.243 & -0.238 \\
\hline Happy-Sad & 楽しいー寂しい & 0.158 & -0.107 & -0.961 \\
\hline Warm-Cold & 温かいー冷たい & -0.669 & 0.202 & -0.482 \\
\hline Contr & on rate & 0.319 & 0.264 & 0.243 \\
\hline
\end{tabular}

each combination of listener and piece. The procedure described above was repeated for the 50 pieces. The listening level was decided by a preliminary experiment as follows: Eight pieces including the softest and the loudest pieces were selected from the 50 pieces. Maintaining the original relative-level-differences among the eight pieces, four listeners adjusted the volume dial in the headphone amplifier to the most suitable level for them. The most suitable levels for one of the pieces were averaged over the four listeners. The dial was fixed at the mean level for that piece. Then the listening level was measured for each piece. The measured level varied with pieces ranging from $L_{\text {Aeq }}=74$ to $84 \mathrm{~dB}$. Musical stimuli were recorded on CDs. Each CD consisted of 10 pieces. Before starting the experiment, the listeners practiced to rate the emotional features for five pieces which were selected from the 50 pieces. Then the listeners took a ten-minute rest, and started the experimental trials. After listening to a $\mathrm{CD}$, the listener took a rest-interval for more than ten minutes. All listeners finished the experiment within three days. The CD tracks appeared in a random order for each listener.

\subsection{Results and Discussion}

Numbers -3 to 3 were given for each of the seven categories on the SD scales. The mean value was calculated from the listeners' responses for each combination of scale and stimulus. Then factor analysis was performed for these mean scores with the principal factor method and varimax rotation. The results of the analysis showed that the orthogonal three-factor solution accounted for $82.6 \%$ of data variance. Table 2 shows the resulting factor loadings. The three factors are labeled "evaluation," "potency" and "activity" respectively, after the scales which show large loadings for these factors. These results show that the emotional space of popular music is constructed by "evaluation," "potency," and "activity" factors. In principle, these factors are identical to the three dimensions of semantic space proposed by Osgood and his colleagues, and the number of the factors agrees with the results from Iwamiya [7], and Yamada, Fujisawa and Komori [8], although not all the names of the factors coincided.

The results shown above are for the top selling pieces in Japan. All of the pieces listed in Table 1 were in the J-POP genre. However, some types of Japanese people often listen to Enka (a type of Japanese traditional popular song), rock, club music and Hip-Hop songs sung in Japanese. Moreover, Japanese listeners sometimes listen to American and European popular music, also. Therefore, using a different set of pieces including different musical genres other than J-POP, Experiment 2 was conducted.

\section{EXPERIMENT 2}

\subsection{Musical Stimuli}

A Japanese commercial company, Sockets Inc., which provides Japanese people extensively with music retrieval and supply systems, provided wave files of 169 musical pieces. The set of the pieces included J-POP and Enka (a type of Japanese traditional popular songs). The set also included, rock, club music and Hip-Hop songs sung in Japanese, as well as western (American and European) popular music sung in English, but did not include classical pieces of music. These 169 pieces are listed in Table 3. The labels Japanese or Western music and the genres for the 
Table 3 Musical pieces used in Experiment 2.

\begin{tabular}{|c|c|c|c|c|}
\hline Title & Artist & $\begin{array}{l}\text { Japanese }(\mathrm{J}) / \\
\text { Western }(\mathrm{W})\end{array}$ & Genre & Tempo [BPM] \\
\hline Polyrhythm & Perfume & $\mathrm{J}$ & Club Music & 128 \\
\hline Electro World & Perfume & $\mathrm{J}$ & Club Music & 143 \\
\hline Kiyoshi No Soran Bushi & Kiyoshi Hikawa & $\mathrm{J}$ & Enka & 99 \\
\hline Ame No Bojo & Aki Yashiro & $\mathrm{J}$ & Enka & 79 \\
\hline Suterarete & Yoko Nagayama & $\mathrm{J}$ & Enka & 105 \\
\hline Mitinoku Hitori Tabi & Gerorge Yamamoto & $\mathrm{J}$ & Enka & 70 \\
\hline Kyoudaibune & Ichiro Toba & $\mathrm{J}$ & Enka & 78 \\
\hline Ora Tokyo Sa Iguda & Ikuzo Yoshi & $\mathrm{J}$ & Enka & 118 \\
\hline Tsugunai & Teresa Teng & $\mathrm{J}$ & Enka & 111 \\
\hline Chindo Monogatari & Yoshimi Tendo & $\mathrm{J}$ & Enka & 94 \\
\hline Yozora & Hiroshi Itsuki & $\mathrm{J}$ & Enka & 117 \\
\hline Amagigoe & Sayuri Ishikawa & $\mathrm{J}$ & Enka & 81 \\
\hline Cherry & SPITZ & $\mathrm{J}$ & J-POP & 97 \\
\hline A Perfect Sky & Bonnie Pink & $\mathrm{J}$ & $\mathrm{J}-\mathrm{POP}$ & 90 \\
\hline $\mathrm{NAO}$ & HY & $\mathrm{J}$ & $\mathrm{J}-\mathrm{POP}$ & 78 \\
\hline Hana & Mr. Children & $\mathrm{J}$ & $\mathrm{J}-\mathrm{POP}$ & 84 \\
\hline Unabara No Tsuki & Yuko Ando & $\mathrm{J}$ & J-POP & 136 \\
\hline One more time, One more chance & Masayoshi Yamazaki & $\mathrm{J}$ & J-POP & 128 \\
\hline Momoiro No Kataomoi & Aya Matsuura & $\mathrm{J}$ & $\mathrm{J}-\mathrm{POP}$ & 154 \\
\hline $\begin{array}{l}\text { A.i.shi.te } \cdot \text { ru no Sign } \\
\sim \text { Watashitachi no Mirai Yosouzu }\end{array}$ & Dreams Come True & $\mathrm{J}$ & J-POP & 72 \\
\hline Happy Days & Ai Otsuka & $\mathrm{J}$ & J-POP & 182 \\
\hline Shiroi Kaito & MY LITTLE LOVER & $\mathrm{J}$ & $\mathrm{J}-\mathrm{POP}$ & 99 \\
\hline $\begin{array}{l}\text { See-Saw Game } \\
\sim \text { Yukan Na Koi No Uta } \sim\end{array}$ & Mr. Children & $\mathrm{J}$ & J-POP & 134 \\
\hline CHE.R.RY & YUI & $\mathrm{J}$ & $\mathrm{J}-\mathrm{POP}$ & 109 \\
\hline Gekkou & Chihiro Onitsuka & $\mathrm{J}$ & J-POP & 75 \\
\hline Kodoku No Kakera & Angela Aki & $\mathrm{J}$ & J-POP & 68 \\
\hline Gogo No Parade & Suga Shikao & $\mathrm{J}$ & $\mathrm{J}-\mathrm{POP}$ & 125 \\
\hline Koishikute & BEGIN & $\mathrm{J}$ & $\mathrm{J}-\mathrm{POP}$ & 73 \\
\hline Yuki No Hana & Mika Nakashima & $\mathrm{J}$ & $\mathrm{J}-\mathrm{POP}$ & 72 \\
\hline Happiness & ARASHI & $\mathrm{J}$ & J-POP & 115 \\
\hline milk tea & Masaharu Fukuyama & $\mathrm{J}$ & $\mathrm{J}-\mathrm{POP}$ & 73 \\
\hline Wanderin'Destiny & globe & $\mathrm{J}$ & J-POP & 105 \\
\hline Junior Sweet & CHARA & $\mathrm{J}$ & $\mathrm{J}-\mathrm{POP}$ & 88 \\
\hline Haneuma Rider & Porno Graffitti & $\mathrm{J}$ & $\mathrm{J}-\mathrm{POP}$ & 126 \\
\hline Deatta Korono Youni & Every Little Thing & $\mathrm{J}$ & $\mathrm{J}-\mathrm{POP}$ & 129 \\
\hline Ame To Namida & Yuzu & $\mathrm{J}$ & $\mathrm{J}-\mathrm{POP}$ & 108 \\
\hline Kibun Jo Jo & mihimaru GT & $\mathrm{J}$ & J-POP & 125 \\
\hline 19 Memories & Miliyah Kato & $\mathrm{J}$ & J-POP & 80 \\
\hline LOVE LOVE LOVE & DREAMS COME TRUE & $\mathrm{J}$ & J-POP & 83 \\
\hline PEACH & Ai Otsuka & $\mathrm{J}$ & J-POP & 147 \\
\hline It's only love & Masaharu Fukuyama & $\mathrm{J}$ & J-POP & 118 \\
\hline Saudade & Porno Graffitti & $\mathrm{J}$ & $\mathrm{J}-\mathrm{POP}$ & 120 \\
\hline Happy Summer Wedding & Morning Musume & $\mathrm{J}$ & J-POP & 126 \\
\hline Guts daze!! & Ulfuls & $\mathrm{J}$ & $\mathrm{J}-\mathrm{POP}$ & 123 \\
\hline Nada Sousou & Ryoko Moriyama & $\mathrm{J}$ & J-POP & 72 \\
\hline Memories & Yui Aragaki & $\mathrm{J}$ & $\mathrm{J}-\mathrm{POP}$ & 107 \\
\hline Eikou No Kakehashi & Yuzu & $\mathrm{J}$ & J-POP & 82 \\
\hline Arigatou.... & KOKIA & $\mathrm{J}$ & J-POP & 69 \\
\hline Makenaide & ZARD & $\mathrm{J}$ & J-POP & 125 \\
\hline Donnani Tokutemo & JUJU & $\mathrm{J}$ & J-POP & 72 \\
\hline Aiuta & GReeeeN & $\mathrm{J}$ & $\mathrm{J}-\mathrm{POP}$ & 85 \\
\hline Yume No Uta & Kumi Koda & $\mathrm{J}$ & $\mathrm{J}-\mathrm{POP}$ & 72 \\
\hline Kaeritaku Nattayo & Ikimonogakari & $\mathrm{J}$ & $\mathrm{J}-\mathrm{POP}$ & 79 \\
\hline Kaerouka & mihimaru GT & $\mathrm{J}$ & $\mathrm{J}-\mathrm{POP}$ & 100 \\
\hline $1 / 2$ & Shoko Nakagawa & $\mathrm{J}$ & J-POP & 246 \\
\hline Yoroshiku Aisyu & Hiromi Go & $\mathrm{J}$ & $\mathrm{J}-\mathrm{POP}$ & 65 \\
\hline Sakura & Kobukuro & $\mathrm{J}$ & J-POP & 84 \\
\hline DON'T WANNA CRY & Namie Amuro & $\mathrm{J}$ & $\mathrm{J}-\mathrm{POP}$ & 99 \\
\hline
\end{tabular}


Acoust. Sci. \& Tech. 34, 3 (2013)

Table 3 continued.

\begin{tabular}{|c|c|c|c|c|}
\hline Title & Artist & $\begin{array}{l}\text { Japanese }(\mathrm{J}) / \\
\text { Western }(\mathrm{W})\end{array}$ & Genre & Tempo [BPM] \\
\hline SEASONS & Ayumi Hamasaki & $\mathrm{J}$ & J-POP & 80 \\
\hline Summer Dream & Tohoshinki & $\mathrm{J}$ & J-POP & 115 \\
\hline Kandagawa & Kaguyahime & $\mathrm{J}$ & $\mathrm{J}-\mathrm{POP}$ & 95 \\
\hline Boku Wa Kuma & Hikaru Utada & $\mathrm{J}$ & Nursery song & 113 \\
\hline Kimi Ni BUMP & Ketsumeishi & $\mathrm{J}$ & R\&B/Hip-Hop & 96 \\
\hline THE SHOW & KREVA & $\mathrm{J}$ & R\&B/Hip-Hop & 87 \\
\hline Rakuen Beibey & RIP SLYME & $\mathrm{J}$ & R\&B/Hip-Hop & 115 \\
\hline Kurenai & X JAPAN & $\mathrm{J}$ & Rock & 156 \\
\hline Fantasista & Dragon Ash & $\mathrm{J}$ & Rock & 192 \\
\hline Sekai Ga Owaru Yoruni & Chatmonchy & $\mathrm{J}$ & Rock & 77 \\
\hline Tsumi To Batsu & Ringo Sheena & $\mathrm{J}$ & Rock & 82 \\
\hline Last Smile & LOVE PSYCHEDELICO & $\mathrm{J}$ & Rock & 89 \\
\hline Kasou & L'Arc $\sim \mathrm{en} \sim$ Ciel & $\mathrm{J}$ & Rock & 110 \\
\hline Cassis & The Gazette & $\mathrm{J}$ & Rock & 101 \\
\hline Space Sonic & ELLEGARDEN & $\mathrm{J}$ & Rock & 208 \\
\hline ZINNIA & OVER ARM THROW & $\mathrm{J}$ & Rock & 216 \\
\hline Eenen & Ulfuls & $\mathrm{J}$ & Rock & 172 \\
\hline Taiyou Ha Tsumi na Yatsu & Southern All Stars & $\mathrm{J}$ & Rock & 100 \\
\hline Konayuki & Remioromen & $\mathrm{J}$ & Rock & 83 \\
\hline Cage & Dir en grey & $\mathrm{J}$ & Rock & 176 \\
\hline Romance & PENICILLIN & $\mathrm{J}$ & Rock & 146 \\
\hline 1/3 No Jyunjo Na Kanjo & SIAM SHADE & $\mathrm{J}$ & Rock & 152 \\
\hline Rosie & aiko & $\mathrm{J}$ & Rock & 85 \\
\hline AM11:00 & HY & $\mathrm{J}$ & Rock & 98 \\
\hline Love is Here & Janne Da Arc & $\mathrm{J}$ & Rock & 154 \\
\hline D-tecnoLife & UVERworld & $\mathrm{J}$ & Rock & 172 \\
\hline Mitsuyubi? Mistuyubi? & Sid & $\mathrm{J}$ & Rock & 207 \\
\hline Sora Ha Marude & MONKEY MAJIK & $\mathrm{J}$ & Rock & 92 \\
\hline Buttobasuzo & Tamurapan & $\mathrm{J}$ & Rock & 130 \\
\hline Ai no corrida & Quincy Jones & $\mathrm{W}$ & Black Music & 126 \\
\hline Love You Inside Out & Bee Gees & W & Black Music & 95 \\
\hline No More Pain & $2 \mathrm{Pac}$ & W & Black Music & 154 \\
\hline Runnin’ Away & Sly \& The Family Stone & W & Black Music & 103 \\
\hline Hot Stuff & Craig David & W & Black Music & 114 \\
\hline Inner City Blues & Marvin Gaye & W & Black Music & 94 \\
\hline Country Grammar & Nelly & $\mathrm{W}$ & Black Music & 82 \\
\hline You Make Me Wanna & Usher & W & Black Music & 82 \\
\hline London Bridge & Fergie & W & Black Music & 91 \\
\hline$\# 1$ & Nelly & W & Black Music & 90 \\
\hline Low feat. T-Pain & Flo Rida & W & Black Music & 128 \\
\hline One Sweet Day & Mariah Carey & W & Black Music & 64 \\
\hline Piece Of Me & Britney Spears & W & Black Music & 115 \\
\hline Umbrella & Rihanna & W & Black Music & 87 \\
\hline Yeah & Usher & W & Black Music & 105 \\
\hline The Rockafeller Skank & Fatboy Slim & W & Club Music & 152 \\
\hline Machine Gun & Portishead & W & Club Music & 106 \\
\hline Scatman's World & Scatman John & $\mathrm{W}$ & Club Music & 146 \\
\hline Scarborough Fair & Simon \& Garfunkel & W & Country/Folk & 87 \\
\hline Blowin' In The Wind & Bob Dylan & W & Country/Folk & 100 \\
\hline Watermark & Enya & $\mathrm{W}$ & Easy Listening & 68 \\
\hline Don't Know Why & Norah Jones & W & Jazz & 88 \\
\hline There Must Be An Angel & Eurythmics & $\mathrm{W}$ & Pops & 113 \\
\hline Iron Man & The Cardigans & $\mathrm{W}$ & Pops & 71 \\
\hline Top Of The World & The Carpenters & W & Pops & 92 \\
\hline Good Enough & Cyndi Lauper & $\mathrm{W}$ & Pops & 137 \\
\hline Wannabe & Spice Girls & $\mathrm{W}$ & Pops & 110 \\
\hline Fairground & Simply Red & $\mathrm{W}$ & Pops & 123 \\
\hline Been To Canaan & Carol King & $\mathrm{W}$ & Pops & 129 \\
\hline New Soul & Yael Nairn & $\mathrm{W}$ & Pops & 101 \\
\hline Miles Away & Madonna & W & Pops & 116 \\
\hline
\end{tabular}


Table 3 continued.

\begin{tabular}{|c|c|c|c|c|}
\hline Title & Artist & $\begin{array}{l}\text { Japanese }(\mathbf{J}) / \\
\text { Western }(\mathrm{W})\end{array}$ & Genre & Tempo [BPM] \\
\hline My Heart Will Go On & Celine Dion & $\mathrm{W}$ & Pops & 50 \\
\hline Sound of Silence & Simon \& Garfunkel & W & Pops & 107 \\
\hline Sing & Carpenters & $\mathrm{W}$ & Pops & 70 \\
\hline Yesterday Once More & Carpenters & W & Pops & 83 \\
\hline Inconsolable & Backstreet Boys & $\mathrm{W}$ & Pops & 80 \\
\hline Thriller & Michael Jackson & W & Pops & 118 \\
\hline Blank Sabbath & Black Sabbath & W & Rock & 65 \\
\hline Roxette & Dr. Feelgood & W & Rock & 127 \\
\hline China White & Scorpions & W & Rock & 82 \\
\hline Riders On The Storm & The Doors & $\mathrm{W}$ & Rock & 103 \\
\hline Analyse & Thorn Yorke & W & Rock & 100 \\
\hline Won't Go Home Without You & Maroon 5 & $\mathrm{~W}$ & Rock & 110 \\
\hline Today & The Smashing Pumpkins & W & Rock & 82 \\
\hline Girlfriend & Avril Lavigne & W & Rock & 164 \\
\hline Can't Stand Me Now & The Libertines & W & Rock & 165 \\
\hline Sunshine Of Your Love & Cream & W & Rock & 115 \\
\hline Who's Crying Now & Journey & $\mathrm{W}$ & Rock & 121 \\
\hline Lady Madonna & The Beatles & W & Rock & 109 \\
\hline Nude & Radiohead & W & Rock & 128 \\
\hline Don't Stop Me Now & Queen & $\mathrm{W}$ & Rock & 156 \\
\hline Bring Me To Life & Evanescence & W & Rock & 95 \\
\hline Message In A Bottle & The Police & W & Rock & 151 \\
\hline If I Had Eyes & Jack Johnson & W & Rock & 92 \\
\hline Ruby Tuesday & The Rolling Stones & W & Rock & 106 \\
\hline Muse & Hysteria & W & Rock & 93 \\
\hline Someday I'll Be Saturday Night & Bon Jovi & W & Rock & 126 \\
\hline Love Today & MIKA & W & Rock & 124 \\
\hline Tears In Heaven & Eric Clapton & $\mathrm{W}$ & Rock & 79 \\
\hline Saturday In The Park & Chicago & $\mathrm{W}$ & Rock & 114 \\
\hline Bulls On Parade & Rage Against The Machine & $\mathrm{W}$ & Rock & 83 \\
\hline Call Me & Blondie & W & Rock & 142 \\
\hline Town Called Malice & The Jam & W & Rock & 202 \\
\hline People=Shit & Slipknot & W & Rock & 121 \\
\hline You Give Love A Bad Name & Bon Jovi & W & Rock & 123 \\
\hline Nobody's Home & Avril Lavigne & $\mathrm{W}$ & Rock & 92 \\
\hline What I've Done & Linkin Park & W & Rock & 120 \\
\hline How Long & Eagles & $\mathrm{W}$ & Rock & 140 \\
\hline Underclass Hero & SUM 41 & W & Rock & 190 \\
\hline Wait and Bleed & Slipknot & W & Rock & 186 \\
\hline Jump & Van Halen & W & Rock & 129 \\
\hline Change The World & Eric Clapton & $\mathrm{W}$ & Rock & 97 \\
\hline To Be With You & Mr. Big & $\mathrm{W}$ & Rock & 82 \\
\hline Stairway to Heaven & Led Zeppelin & $\mathrm{W}$ & Rock & 89 \\
\hline Yesterday & The Beatles & W & Rock & 100 \\
\hline We Will Rock You & Queen & $\mathrm{W}$ & Rock & 82 \\
\hline Heart-Shaped Glasses & Marilyn Manson & $\mathrm{W}$ & Rock & 125 \\
\hline Going Under & Evanescence & W & Rock & 87 \\
\hline Detroit Rock City & Kiss & W & Rock & 190 \\
\hline Jigsaw Falling Into Place & Radiohead & $\mathrm{W}$ & Rock & 164 \\
\hline Heartbeat & Tahiti 80 & $\mathrm{~W}$ & World Music & 109 \\
\hline Mas Que Nada & Sergio Mendes \& BRASIL '66 & $\mathrm{W}$ & World Music & 175 \\
\hline
\end{tabular}

pieces were provided by Sockets Inc. The number of the pieces for each genre may reflect the practical ratio in the situation of Japanese people's listening behavior. None of the pieces in Table 3 was used in Experiment 1. The play time of the pieces ranged from 3.5 to $7.0 \mathrm{~min}$.

\subsection{Procedure}

Three musicians who graduated from the Department of Music, Osaka University of Arts, and eight nonmusicians from the Kanazawa Institute of Technology participated in Experiment 2. All of the three musicians 
were male, and their ages ranged from 31 to 50 . Nonmusicians consisted of seven males and one female and their ages ranged from 20 to 23. Two of the musicians participated also in Experiment 1 and none of the nonmusicians participated in Experiment 1. The musicians listened to at least several pieces from various genres a day, and non-musicians listened to J-POP pieces at least once a day. They listened to the 169 pieces and rated them. The listeners rated the emotional features for each piece, using the same SD scales as in Experiment 1. The listeners also rated the degree of suitability of it using seven-step scales for four different situations; "listening alone," "listening with his/her lover," "listening with people around him/ her," "listening with a high level of concentration." The SD scales and the scales of the suitability for four situations appeared on a response sheet in a random order for each combination of listener and piece. For deciding the listening level, the same procedure was used as Experiment 1 . The listening level varied with pieces $\left(L_{\text {Aeq }}=\right.$ $70-84 \mathrm{~dB}$ ). Musical stimuli were presented by CD. Each $\mathrm{CD}$ consisted of 10 pieces. Before starting the experiment, the listeners practiced to rate the emotional features for five pieces which were selected from the 169 pieces. Then the listeners took a ten-minute rest, and started the experimental trials. After listening to a CD, a listener took a rest interval for more than ten minutes. All listeners finished the experiment within a week. The CD tracks appeared in a random order for each listener.

\subsection{Results and Discussion}

The mean value was calculated for each combination of scale and stimulus. Then factor analysis was performed for the mean scores with the principal factor method and varimax rotation. The results of the analysis showed that the orthogonal three-factor solution accounted for $85.1 \%$ of data variance. Table 4 shows the resulting factor loadings. The three factors are labeled "evaluation," "potency" and "activity" respectively, after the scales which show large loadings for these factors. In principle, these factors are identical to the three factors in Experiment 1.

In the next stage, multiple-regression analyses were performed to investigate the correlations between the
Table 4 Semantic differential (SD) scales and factor loadings of them in Experiment 2.

\begin{tabular}{crrr}
\hline & \multicolumn{3}{c}{ Factor } \\
\cline { 2 - 4 } SD scale & Evaluation & Potency & Activity \\
\hline Mixed-Neat & 0.741 & -0.524 & -0.204 \\
Clean-Dirty & -0.925 & 0.203 & -0.016 \\
Showy-Humble & 0.267 & -0.762 & -0.463 \\
Agitated-Calm & 0.639 & -0.573 & -0.435 \\
Fresh-Sordid & -0.869 & 0.159 & -0.310 \\
Heavy-Light & 0.489 & -0.384 & 0.735 \\
Dark-Bright & 0.277 & 0.157 & 0.935 \\
Cheerful-Gloomy & 0.008 & -0.083 & -0.972 \\
Weak-Strong & -0.301 & 0.850 & -0.003 \\
Hard-Soft & 0.768 & -0.563 & 0.042 \\
Loose-Tight & -0.154 & 0.803 & -0.149 \\
Powerful-Powerless & 0.273 & -0.925 & 0.057 \\
Monotonous-Varied & 0.086 & 0.631 & 0.150 \\
Tranquil-Restless & -0.609 & 0.622 & 0.320 \\
Pleasant-Unpleasant & -0.869 & -0.120 & -0.303 \\
Happy-Sad & 0.044 & -0.191 & -0.951 \\
Warm-Cold & -0.646 & 0.197 & -0.533 \\
\hline Contribution rate & 0.311 & 0.285 & 0.255 \\
\hline
\end{tabular}

emotional features and suitable situations for listening. Factor scores of the "evaluation," "potency" and "activity" were used as explanation variables, and the degree of the suitability for a situation was used as a criterion variable in each analysis. The results showed that the coefficient of determination, $R^{2}$, was larger than 0.5 for the situations of "listening with his/her lover" and "listening with people around him/her" (Table 5). Figure 1 shows the multiple-regression lines for the two situations as vectors. Figure 1 suggests that Japanese listeners like to listen to a "beautiful" tune of popular music with their lovers, and a "powerful" and "active" tune in a situation where people are around them.

Moreover, the tempo for each piece was measured in BPM. In this measurement, one of the authors matched the tempo of a metronome for each piece. The measured tempi are shown in Table 3. The correlation between the tempo and the emotional features was investigated with multipleregression analysis. The results showed that the coefficient

Table 5 The correlations between emotional features vs. suitable situations for listening and tempo in BPM.

\begin{tabular}{|c|c|c|c|c|}
\hline \multirow{2}{*}{ Situation } & \multirow{2}{*}{$\begin{array}{c}\text { Coefficient of } \\
\text { determination }\left(R^{2}\right)\end{array}$} & \multicolumn{3}{|c|}{ Multiple-regression coefficient } \\
\hline & & Evaluaion & Potency & Activity \\
\hline listening with people around him/her & 0.58 & -0.01 & 0.28 & 0.45 \\
\hline listening with his/her lover & 0.68 & 0.80 & -0.03 & 0.29 \\
\hline listening with a high level of concentration & 0.45 & 0.29 & 0.35 & -0.21 \\
\hline listening alone & 0.35 & 0.38 & 0.06 & -0.14 \\
\hline BPM & 0.01 & -3.85 & -2.07 & 2.50 \\
\hline
\end{tabular}



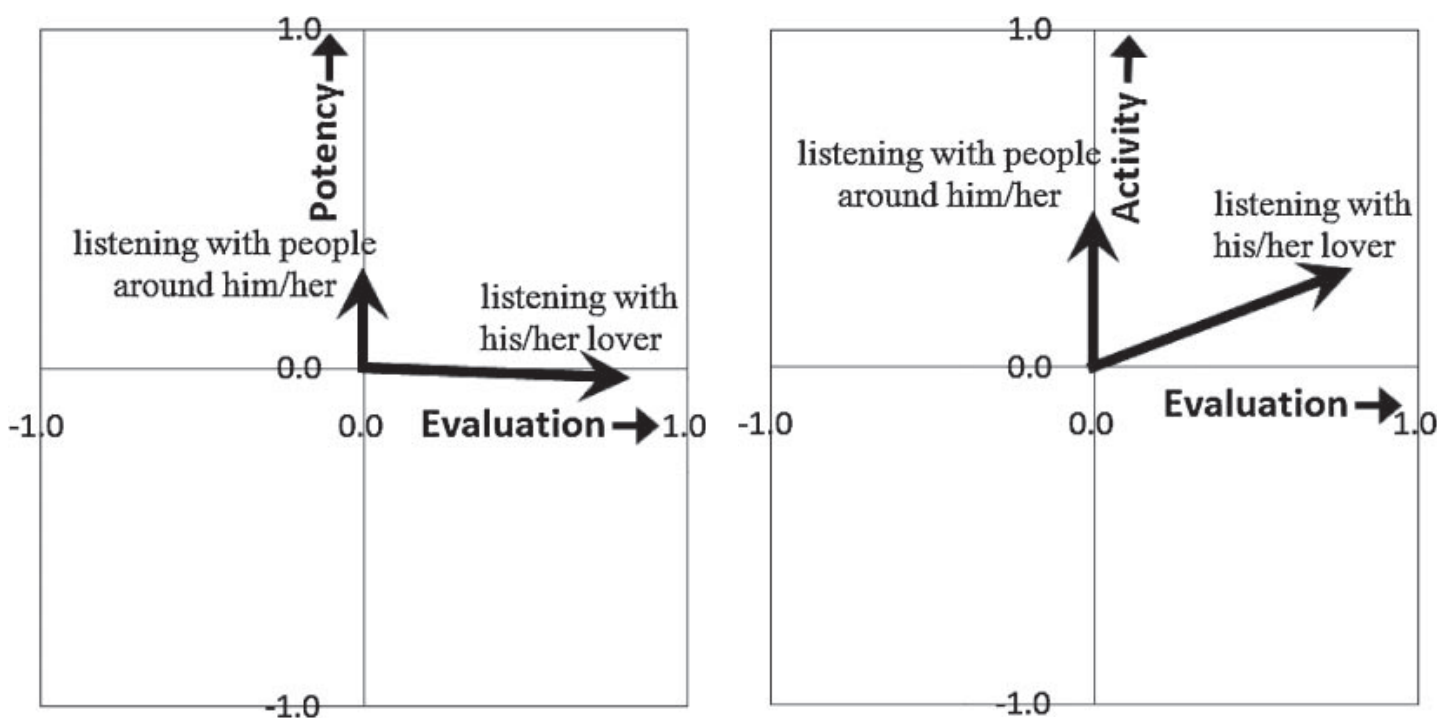

Fig. 1 The results of multiple-regression analyses. Each vector shows the degree of suitability for a listening situation.
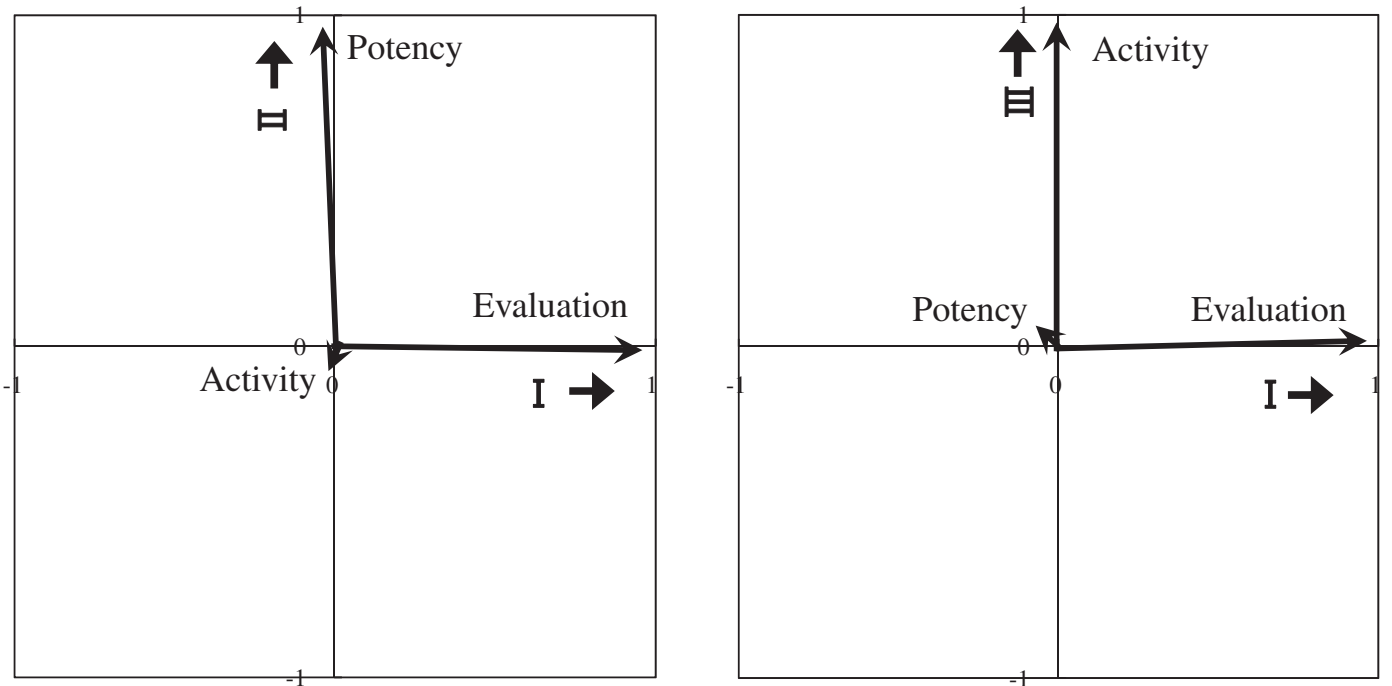

Fig. 2 The vectors, evaluation, potency and activity, which are obtained by the factor analysis are potted on the threedimensional space spanned by I, II and III dimensions, obtained by multi-dimensional scaling.

of determination, $R^{2}$, was 0.01 (Table 5). The results suggest that only one parameter of tempo was not enough to illustrate any part of the emotional features in popular music.

In Experiment 2, three musicians and eight nonmusicians participated as listeners. In the final stage of the analysis, a multi-dimensional scaling was performed to reveal whether the perception of the emotional features was different or not between the three musicians and the eight non-musicians. Let the score of an SD scale $j$ by a listener $i$ for a piece A, $S_{\mathrm{A} i j}$. Then the perceptual distance between two pieces, $\mathrm{A}$ and $\mathrm{B}$, was defined as follows:

$$
d_{\mathrm{AB}}=\sum_{i=1}^{11} \sum_{j=1}^{17}\left|S_{\mathrm{A} i j}-S_{\mathrm{B} i j}\right|
$$

Using these distances, a multi-dimensional scaling was performed using Proxscal. The results showed that the stress value was 0.06 for the three-dimensional solution. Then, multiple-regression analyses were performed using the three coordination values of the pieces as explanation variables, and with the factor score of each factor of the "potency," "activity" and "evaluation" as criterion variables. The resulting coefficients of determination were 0.9 . Figure 2 shows the "evaluation," "potency" and "activity" factors as vectors on the three-dimensional space which was acquired from the multi-dimensional scaling. Figure 2 shows that each of the three dimensions almost completely coincides with the three factors "evaluation," "potency" and "activity," respectively. Proxscal also calculated the individual space for each listener. The individual space was 
Table 6 The ratio of the weights of "potency" and "activity" to that of the "evaluation" for each listener.

\begin{tabular}{ccccc}
\hline \multirow{2}{*}{ Listener } & & \multicolumn{3}{c}{ Ratio of Weights } \\
\cline { 3 - 5 } & & Evaluation & Potency & Activity \\
\hline Non-musician & S1 & 1.00 & 1.01 & 1.03 \\
& S2 & 1.00 & 1.01 & 1.01 \\
& S3 & 1.00 & 1.01 & 1.08 \\
& S4 & 1.00 & 1.00 & 1.10 \\
& S5 & 1.00 & 1.01 & 1.08 \\
& S6 & 1.00 & 1.01 & 0.98 \\
& S7 & 1.00 & 1.01 & 1.05 \\
& S8 & 1.00 & 1.03 & 0.85 \\
\hline \multirow{6}{*}{ Musician } & S9 & 1.00 & 1.00 & 1.22 \\
& S10 & 1.00 & 1.02 & 0.95 \\
& S11 & 1.00 & 1.03 & 0.91 \\
\hline
\end{tabular}

expressed with the weights for the three-dimensions. Then the ratios of the weights for "potency" and "activity" to the weight of "evaluation" were calculated for each listener. The resulting ratios are shown in Table 6. Table 6 shows that the weight-balance for the three dimensions does not vary largely among the listeners. This implies that there are no significant differences in the perception of emotional features between the musicians and non-musicians for popular music, in the case of the present experiment. It may be difficult to say that there are no significant differences in the perception of emotional features between musicians and non-musicians in general, because the number of musicians and non-musicians was limited in the present experiment. In the near future, the perception of emotional features between a large number of musicians and non-musicians in general should be compared.

\section{GENERAL DISCUSSION}

In Experiments 1 and 2, the practice trials were performed for five pieces before starting the experimental trials. The five pieces were selected from the pieces for the experimental trials. To test the effect of fatigue on the rating of the emotional features, the scores on the 17 SD scales for the five pieces were compared between the practice trials and experimental trials. The results showed that the accumulated difference of the scores for a piece was smaller than ten steps for all listeners in both experiments. This implies that the mean difference on a SD scale was within 0.6 steps between the practice and experimental trials. The experimental trial was apart several days, in maximum, from the practice trial for a piece. This may imply that the fatigue did not affect the rating of the emotional features significantly.

In Experiments 1 and 2, the rated scores were averaged over the listeners for each combination of scale and stimulus, and the factor analyses were performed for these mean scores. The results of the analyses showed the threefactor solutions as shown in Tables 2 and 4. These threefactor solutions indicate the averaged features of the emotional perception over the listeners. Using the raw data in Experiment 2, factor analysis was also performed. The results showed that the four-factor resolution accounted for only $65.0 \%$ of the data variance. These results may imply that the perception of the emotional features of a specific piece was somehow different among different listeners, although the perception does not vary largely among the listeners throughout the 169 pieces as Table 6 shows. In other words, there may be interactions between the pieces and the individual listeners in the perception of emotional features. Such interactions should be investigated in the near future.

In Experiment 2, the multiple-regression analysis was performed using the factor scores of the "evaluation," "potency" and "activity" as explanation variables, and tempo in BPM as the criterion variable. The results showed that the coefficient of determination, $R^{2}$, was as small as 0.01 . It is obvious that the results of a single regression analysis, using the tempo as an explanation variable and one of the factor scores as a criterion variable, will show a smaller value of $R^{2}$ than 0.01 . This implies that only one parameter of tempo cannot illustrate any of the three factors, "evaluation," "potency" or "activity."

\section{CONCLUSION}

In the present study, emotional space of current Japanese popular music was investigated. The number of the listeners was limited, because the number of musical pieces was given priority over the number of listeners. The results showed that the emotional space of popular music is constructed by "evaluation," "potency" and "activity" factors. Moreover, it is shown that Japanese listeners like to listen to a "beautiful" tune of popular music with their lovers, and a "powerful" and "active" tune in a situation where people are around them. Furthermore, it was shown that only one parameter of tempo was not enough to illustrate any part of the emotional features in popular music. Tempo may vary the emotional features significantly in the situation where simple musical materials are used as stimuli, and tempo varies systematically. However, in a large set of musical pieces, many parameters, such as tempo, spectral centroid, articulation, level and tonality, may cooperate to affect the emotional features in music.

The results shown above are for the current popular music in Japan, and rated by Japanese listeners. Similar studies should be carried out with different sets of popular musical pieces and listeners from different cultures. It would also be interesting to investigate the effects of sung language (mother language or not) on the emotional features. 


\section{ACKNOWLEDGEMENT}

The authors thank Sockets Inc. for their cooperation. This work was partly supported by a Grant-in-Aid for Scientific Research (C), No. 22615043, from the Ministry of Education, Culture, Sports, Science and Technology, Japan.

\section{REFERENCES}

[1] K. Hevner, "Expression in music: A discussion of experimental studies and theories," Psychol. Rev., 42, 186-204 (1935).

[2] K. Hevner, "The affective value of pitch and tempo in music," Am. J. Psychol., 49, 621-630 (1937).

[3] C. E. Osgood, G. J. Suci and P. H. Tannenbaum, The Measurement of Meaning (University of Illinois Press, Urbana, 1957).

[4] J. A. Russell, "A circumplex model of affect," J. Pers. Soc. Psychol., 39, 1161-1178 (1980).

[5] E. Schubert, "Continuous measurement of self-report emotion response to music," in Music and Emotion: Theory and Research, P. Juslin and J. Sloboda, Eds. (Oxford University Press, New York, 2001), pp. 393-414.

[6] T. Taniguchi, Ongaku to Kanjoh (Music and Emotion) (Kitaohji Shobo, Kyoto, 1998), pp. 89-117 (in Japanese).

[7] S. Iwamiya, "Interaction between auditory and visual processing in car audio: Simulation experiment using video reproduction," Appl. Hum. Sci., 16, 115-119 (1997).

[8] M. Yamada, N. Fujisawa and S. Komori, "The effect of music on the performance and impression in a video racing game," J. Music Percept. Cognit., 7, 65-76 (2001).

[9] H. dela Motte-Haber, Ein Beitrag zur Klassifikation musika- lischer Rhythmen (Arno Volk Verlag, Köln, 1968).

[10] A. Gabrielsson, "Adjective ratings and dimension analysis of auditory rhythm patterns," Scand. J. Psychol., 14, 244-260 (1973).

[11] A. Gabrielsson and E. Lindstörm, "Emotional expression in music performance: Between the performer's intention and the listener's experience," Psychol. Music, 24, 8-91 (1995).

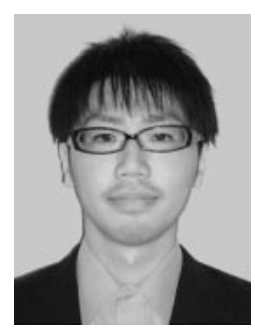

Ryo Yoneda was born in Toyama in 1986. He received B. E. and M. E. degrees from the Kanazawa Institute of Technology in 2009 and 2011, respectively. He is currently a doctoral candidate in the Graduate School of Engineering, Kanazawa Institute of Technology, and has been since 2011. His research interests include music perception and emotion. He is a member of the ASJ and the JSMPC.

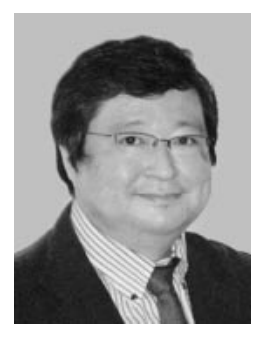

Masashi Yamada received his B. A. in Music from the Osaka Univ. of Arts in 1982, and B. S. in Mathematics from the Osaka Pref. Univ. in 1985, and his M. Design and Ph. D. from the Kyushu Institute of Design in 1987 and 1998, respectively. He worked for the Osaka Univ. of Arts from 1987 to 1994 as a Research Associate and an Assistant Professor. He joined the Kanazawa Institute of Technology in 1994 as an Associate Professor and is currently a Professor. The ASJ awarded him the Awaya-Kiyoshi Prize in 1992, and also the Sato Paper Prize in 1999 and 2004, respectively. His research interests include music acoustics, music psychology and entertainment engineering. 